\title{
From special powers to legislating the lockdown: the Health Protection (Coronavirus, Restrictions) Regulations (Northern Ireland) 2020*
}

\author{
Daniel Holder \\ Committee on the Administration of Justice, Belfast \\ Correspondence email: daniel@caj.org.uk
}

\begin{abstract}
The Health Protection (Coronavirus, Restrictions) Regulations (Northern Ireland) 2020 were made through temporarily inserted provisions by Westminster's vast and rushed Coronavirus Act 2020. This itself limits duties to notify deaths to the coroner, despite Article 2 European Convention on Human Rights duties being particularly relevant to deaths in care homes and of frontline workers. The regularly amended March 2020 Northern Ireland regulations have themselves raised 'legal certainty' issues. Until June, official websites carried no accessible information as to their scope. Initial concerns on lack of clarity over matters such as driving for exercise gave way to greater controversy regarding the application of the regulations to the Black Lives Matter protests on 6 June 2020 through Police Service of Northern Ireland powers that had only been extended through an eleventh hour amendment the night before. The enforcement powers themselves are so widely drafted that they are reminiscent of the Special Powers Acts of the past. These issues are explored in this article.
\end{abstract}

Keywords: COVID-19; emergency legislation; Northern Ireland; Health Protection (Coronavirus, Restrictions) Regulations (Northern Ireland) 2020; Special Powers Acts; Black Lives Matter; Common Travel Area; inquests.

\section{INTRODUCTION}

$\mathrm{N}_{\mathrm{t}}$ orthern Ireland (NI) is no stranger to emergency legislation. From the Special Powers Acts, ${ }^{1}$ Troubles-era legislation, ${ }^{2}$ the 'normalised'

* $\quad$ First published in NILQ 71.4 (2020) Winter: 537-555.

1 The Civil Authorities (Special Powers) Act (Northern Ireland) 1922 remained on the statute books for the lifetime of the Stormont Parliament. The legislation was repealed under direct rule (by the Northern Ireland (Emergency Provisions) Act 1973). For analysis on its operation see: Laura K Donohue, 'Regulating Northern Ireland: the Special Powers Acts 1922-1972’ (1999) 41(4) Historical Journal 1089-1120.

2 Northern Ireland (Emergency Provisions) Act 1973. See also the Prevention of Terrorism (Temporary Provisions) Act 1974 and subsequent Acts. 
and post-9-11 provisions, ${ }^{3}$ and residual NI-specific measures, ${ }^{4}$ such powers have been in place throughout its existence. The COVID-19 pandemic presents a different type of proposition in that urgent and quite different provisions are required to save lives in the context of a public health emergency that is unprecedented in living memory.

Like all emergency law, such provisions must be compatible with human rights obligations that require restrictions to be inter alia proportionate, time-bound and non-discriminatory. There is also the requirement of legal certainty (in essence, the rules must be clear). There are also positive obligations, including duties to safeguard vital socioeconomic well-being, but also the 'right to life' duties under European Convention on Human Rights (ECHR) Article 2. These require public authorities to take all reasonable steps to save lives and also encompass duties to investigate certain deaths to which acts or omissions of public authorities may have contributed. This duty is of particular importance in the context of the UK having reportedly surged to have the highest COVID-19 death toll in Europe, ${ }^{5}$ raising the prospects of thousands of additional avoidable deaths having been resultant from high-level policy decisions, and the urgent need to 'learn lessons' before any future surge.

The UK government chose not to utilise the existing Civil Contingencies Act 2004 and instead rushed through Westminster the vast Coronavirus Act 2020. This Act contains NI-specific provision and also temporarily inserts a new section in the existing Stormont-era Public Health Act (Northern Ireland) 1967 (PHANI 1967), augmenting wide regulation-making powers. It is the modified PHANI 1967 that enables the Health Protection (Coronavirus, Restrictions) Regulations (Northern Ireland) 2020 (NI COVID-19 Regulations), which constitute the principle emergency provisions in this jurisdiction introduced in response to COVID-19. The original NI COVID-19 Regulations were made, laid before the Assembly and came into force on 28 March 2020.

Whilst measures restricting movement, assembly and liberty are necessary in the context of a deadly pandemic, the NI COVID-19 Regulations are not without their issues. The enforcement powers for

3 The Terrorism Act 2000 provided permanent UK-wide provisions and replaced the Northern Ireland (Emergency Provisions) Act 1996 and the Prevention of Terrorism (Temporary Provisions) Act 1989. Post 2001, there were a further series of legislative provisions including: Anti-Terrorism, Crime and Security Act 2001; Terrorism Act 2006; Counter Terrorism Act 2008; Terrorist Asset Freezing etc Act 2010; Terrorism Prevention and Investigations Measures Act 2011; Protection of Freedoms Act 2012; and Counter Terrorism and Security Act 2015.

$4 \quad$ Justice and Security (Northern Ireland) Act 2007.

5 See Robert Booth and Pamela Duncan 'UK coronavirus death toll passes 50,000, official figures show' The Guardian (2 June 2020) citing research by Johns Hopkins University. 
some regulations are so vague and arbitrary (providing that a 'relevant person may take such action as is necessary to enforce any requirement') they are reminiscent of the Special Powers Acts. Questions over legal certainty have also arisen. Initially, this concerned the extent the 'stay at home' rule permitted travel for exercise where initial Police Service of Northern Ireland (PSNI) statements were contradictory. In addition, there are issues with public dissemination and transparency, key conditions for the rule of law, since for several months there was no official public website where the restrictions under the NI COVID-19 Regulations were clearly set out. For the minority of the public who may be used to reading legislation, a consolidated version of the NI COVID-19 Regulations (which by 12 June 2020 had been amended six times) was also not available for some time. A brief period of legal limbo has also occurred between the announcement of certain changes and the law being duly altered. The problems this poses had been mitigated by a general policing response that had not been widely considered as heavy-handed. However, this changed in the context of the issuing of fines and other enforcement measures by the PSNI against Black Lives Matter anti-racism protests on Saturday 6 June 2020, making use of an extension of enforcement powers to outdoor gatherings, through an amendment to the NI COVID-19 Regulations that had only been made and commenced the night before. ${ }^{6}$ Whilst at the time of writing the direction of travel is to ease the regulations as part of the Executive roadmap out of lockdown, restrictions may be reintroduced in response to any second wave, providing an opportunity for necessary modifications in the interim.

In June 2020 a new separate set of regulations was also made by the NI Department of Health to enforce a 14-day 'self-isolation' rule for persons returning to Northern Ireland from outside the (UK/Ireland) Common Travel Area (CTA). ${ }^{7}$ The regulations, made on a Friday and commenced the following Monday with limited prior Assembly scrutiny, contain significant ambiguities, particularly in relation to reentry over the land border.

This commentary explores these issues in detail. It does so by first considering the applicable human rights law framework, before moving to look at the initial moves to legislate on these islands in response to the pandemic, and finally turning specifically to examine the outworking of the Coronavirus Act 2020 and the NI COVID-19 Regulations, paying specific attention to some of the key vagaries.

6 See 'Coronavirus: "Between 60 and 70" fines at anti-racism protests' BBC News (8 June 2020); and 'Laws restricting protest in Northern Ireland "unacceptable"' Press Statement (Amnesty International and CAJ, 8 June 2020).

7 The Health Protection (Coronavirus, International Travel) Regulations (Northern Ireland) 2020. 


\section{THE HUMAN RIGHTS LAW FRAMEWORK}

The framework provided by human rights law shapes the legislative response to the pandemic through both providing for positive obligations and limitations on the extent rights can be restricted. This includes the ECHR, directly applicable in the courts by virtue of the Human Rights Act 1998.

The positive obligations include binding duties under Article 2 ECHR (right to life) on public authorities to take all reasonable steps to save lives. The parameters of such obligations can be shaped by related international standards, including those in UN instruments on the right to health 8 and World Health Organization standards. Significant questions have arisen regarding the initial UK divergence from such standards in areas such as case finding, contact tracing and testing, along with preventing COVID-19 in care homes. ${ }^{9}$

The UK having surged to Europe's reported highest COVID-19 death toll points to countless thousands of additional avoidable deaths having consequently resulted from acts or omissions of public authorities. Such a context engages a broader set of procedural ECHR Article 2 duties to ensure there are prompt, effective investigations, independent of those responsible, into certain deaths. Domestically, the coronial inquest system can provide such a mechanism, whereby, for example, the contribution of acts or omissions of public authorities to the death of a frontline worker, including those resultant from government policy, could both be the triggering factor requiring an inquest and shape the parameters of the matters it examines. There is also the broader role of public inquiries ensuring 'lessons learned' lead to non-recurrence of failings. The present legislative basis is, however, not without its problems, with the controversial Inquiries Act 2005

8 Including Article 12 (right to highest attainable standard of health) and other provisions (including Article 7(b) on rights to safe and healthy working conditions) under the UN International Covenant on Economic, Social and Cultural Rights (ICESCR).

9 For further discussion, see: 'Editorial: Covid-19: why is the UK government ignoring WHO's advice?' 368 British Medical Journal (30 March 2020); and written evidence to the UK Parliament from Dr Oliver Lewis (Barrister at Doughty Street Chambers, London, and Professor of Law and Social Justice at the School of Law, University of Leeds) and Dr Andrew Kirby (Associate Professor in Microbiology, School of Medicine, University of Leeds, UK) 'The UK government's guidance on combating coronavirus in care homes is inconsistent with WHO standards' (COV0043). 
permitting ministerial interference at numerous stages of a public inquiry. 10

A broader set of positive obligations on the state party include those to ensure the socioeconomic well-being of the population during the emergency. ${ }^{11}$

The second limb of human rights obligations relates to the extent rights can be restricted in an emergency. In general, many rights protected by the ECHR are themselves qualified and can be restricted in accordance with their own limitation clauses. These provide for restrictions which are proportionate in pursuit of a legitimate aim including 'health' and the right to life of others. Many of the measures introduced to contain a pandemic will by their nature restrict rights such as rights to freedom of movement, freedom of assembly, and detention without trial (eg for purposes of testing, treatment or precautionary quarantining).

The general principles around these measures are that restrictions on such rights should: be proportionate, only used for the purpose of containing the pandemic and not unlawful collateral purposes; ${ }^{12}$ be time-bound for only as long is as necessary; be applied in a nondiscriminatory manner; and afford 'legal certainty'. The legal certainty requirements mean the rules need to be clear and the consequences for non-compliance foreseeable (particularly when they invoke criminal sanctions) to ensure citizens and law enforcement personnel alike can regulate their conduct.

More sweeping interference in rights at the time of an emergency will require a temporary derogation from human rights obligations. Under Article 15 of the ECHR a contracting state party can derogate from most ECHR rights for an emergency threatening the life of the nation to the extent strictly required by the exigencies of the

10 The Inquiries Act 2005 was rushed through Parliament to replace all other statutory basis for a public inquiry on the back of the (still outstanding) commitment by the UK to hold a public inquiry into the death of Pat Finucane. For commentary, see The Apparatus of Impunity? (CAJ/Queen's University Belfast 2015).

11 For analysis of many of the issues, see Juan Pablo Bohoslavsky, 'COVID-19: urgent appeal for a human rights response to the economic recession' (UN Independent Expert on the effects of foreign debt and other related international financial obligations of States on the full enjoyment of all human rights, particularly economic, social and cultural rights, Geneva, 15 April 2020).

12 An example of the misuse of emergency-type powers for collateral (ie different) purposes, includes the current concerns regarding the use of counter-terrorism questioning powers in ports in the CTA for routine immigration control purposes. See BrexitLawNI, Policy Report: Brexit, Border Controls and Free Movement (Queen's University Belfast 2018) 23-24. The collateral use of a statutory power can be unlawful under UK law. See, for example, $R(C C) v$ Commissioner of Police of the Metropolis and Another [2012] 1 WLR 1913. 
situation. ${ }^{13}$ A number of such derogations were made in respect of NI during the 'Troubles'. This can include ECHR rights such as rights to liberty and free assembly but does not extend to forced labour, torture, or measures that impinge on the right to life. The Council of Europe is to be notified of derogations. It is only a sovereign government that can apply for a derogation and not a devolved administration, or any other public authority. The latter scenario was highlighted early in the pandemic when Mr Justice Hayden in the England and Wales Court of Protection, dealing with the transfer of a person from a care home in the context of COVID-19, thought he could invoke a derogation from the ECHR on his own. ${ }^{14}$

The UK has not derogated from the ECHR in the context of the pandemic, and therefore all restrictions must be in conformity with the limitation clauses to ECHR rights. Internationally, human rights protection during states of emergency has remained a topic of key concern. The UN Special Rapporteur (UNSR) on counter terrorism and human rights, Fionnuala Ní Aoláin, produced a detailed report on human rights protection and states of emergency in 2018.15 In March 2020, UNSRs and other UN Human Rights Experts urged states not to use COVID-19 emergency measures to suppress human rights. ${ }^{16}$

13 ECHR Article 15 derogation in time of emergency:

' 1 . In time of war or other public emergency threatening the life of the nation any High Contracting Party may take measures derogating from its obligations under this Convention to the extent strictly required by the exigencies of the situation, provided that such measures are not inconsistent with its other obligations under international law.

2. No derogation from Article 2, except in respect of deaths resulting from lawful acts of war, or from Articles 3, 4 (paragraph 1) and 7 shall be made under this provision.

3. Any High Contracting Party availing itself of this right of derogation shall keep the Secretary General of the Council of Europe fully informed of the measures which it has taken and the reasons therefore. It shall also inform the Secretary General of the Council of Europe when such measures have ceased to operate and the provisions of the Convention are again being fully executed.

14 BP $v$ Surrey County Council \& Another [2020] EWCOP 17 (25 March 2020) cited in Stevie Martin, 'A domestic court's attempt to derogate from the ECHR on behalf of the United Kingdom: the implications of Covid-19 on judicial decisionmaking in the United Kingdom' (Blog of European Journal of International Law, 9 April 2020).

15 UN Doc A/HRC/37/52 'Report of the Special Rapporteur on the promotion and protection of human rights and fundamental freedoms while countering terrorism on the human rights challenge of states of emergency in the context of countering terrorism' (UN General Assembly 1 March 2018).

16 Office of the UN High Commissioner for Human Rights, 'COVID-19: States should not abuse emergency measures to suppress human rights - UN experts' (Geneva, 16 March 2020). 


\section{COVID-19: PANDEMIC TO ST PATRICK'S DAY - THE FIRST MOVES TO LEGISLATE}

In the UK the first emergency regulations were laid at Westminster on 10 February 2020 and only applied to England. 17 The regulations were made under the English equivalent of the PHANI 1967 and as such relied on public health legislation and not the Civil Contingencies Act. ${ }^{18}$ The regulations gave health professionals, and (strangely) the Secretary of State, powers to detain persons suspected of having COVID-19 for screening, assessment and isolation (quarantine). The regulations also provide police officers with powers to enforce detention and detain persons who abscond from detention. The UK government stated at the time that it might formalise the regulations across the devolved administrations with the introduction of a Coronavirus Bill. 19

It was March before these regulations were accompanied by others elsewhere on these islands. St Patrick's Day (17 March) was a particularly busy day. In Scotland, the Health Minister placed the National Health Service (NHS) on an emergency footing, citing powers under section 1 and section 78 of the NHS (Scotland) Act 1978.20 In Wales, regulations (similar to those in England) were laid before the Welsh Assembly. ${ }^{21}$ The Irish Cabinet also approved the Health (Preservation and Protection and other Emergency Measures in the Public Interest) Bill 2020. This Bill covered a number of social protection measures, extra powers to restrict public events and travel, and further powers for medical professionals to detain and isolate potentially infected persons. ${ }^{22}$

Substantive emergency legislation was not progressed in NI at this time. There were a number of ministerial statements from the Health Minister Robin Swann MLA. ${ }^{23}$ This included announcing on Monday 2 March 2020 that PHANI 1967 had been amended to include COVID-19 under the list of notifiable (infectious) diseases. In addition, the NI health visitor regulations were amended to include 'Coronavirus

17 Health Protection (Coronavirus) Regulations 2020: see Department of Health and Social Care 'Secretary of State makes new regulations on coronavirus' (10 February 2020). For a critique see Jim Duffy, 'Corona-vires: has the Government exceeded its powers?' (UK Human Rights Blog, 13 February 2020).

18 Section 45R of the Public Health (Control of Disease) Act 1984 (chapter 22).

19 HL Deb 9 March 2020, vol 802, cols 426-7GC.

20 Scottish Government, 'Coronavirus (COVID-19): speech by Cabinet Secretary for Health and Sport' (17 March 2020).

21 Health Protection (Coronavirus) (Wales) Regulations 2020 SR 2020/308 (W 68).

22 Irish Government, 'Government approves legislation to support national response to COVID-19’ (17 March 2020). The Bill passed through Dáil Éireann then the Seanad on 19 and 20 March 2020 respectively.

23 Department of Health, 'DoH ministerial announcements and statements 2020'. 
Disease (COVID-19)' under the list of diseases for which no charges can be levied against any person for NHS treatment. ${ }^{24}$ This means persons who are not 'ordinarily resident' in NI (and hence classed as 'visitors'), including migrants who find themselves in an irregular immigration situation (possibly due to loss of employment because of the pandemic) can avail themselves of free treatment for COVID-19.

Other 'positive action' measures have also been legislated for. The Communities Minister Deirdre Hargey MLA brought in a new Discretionary Support Grant for living expenses due to Coronavirus and pushed through legislation to limit evictions to prevent homelessness during the crisis - extending the notice to quit from one to three months. ${ }^{25}$ There are still some gaps in social protection for migrants due to the Home Office 'no recourse to public funds' rules.

A week on from St Patrick's Day and the initiation of a de facto lockdown in NI (as for example, many schools had closed their doors), the NI Assembly debated and passed a Legislative Consent Motion to what would become the Coronavirus Act 2020.26

\section{THE CORONAVIRUS ACT 2020}

Rather than relying on the existing regulation-making powers in the Civil Contingencies Act the British government instead fast-tracked hefty new primary legislation: a move that has not gone without criticism. ${ }^{27}$ What would become the 359-page Coronavirus Act was introduced into Westminster on 19 March 2020 and was law a week later. As set out in one critique by Professor Clive Walker and Dr Andrew Blick:

Rather than turning to the laws already in place to handle crises like the pandemic, Parliament fast-tracked the Coronavirus Act 2020 ... with scant debate of its shabbily drafted contents over just seven days toward the end of March. Parliament then vanished into recess for four weeks. In addition, the government installed without any scrutiny in any form regulations under the [England] PHA [Public Health Act] 1984.28

24 Provision of Health Services to Persons Not Ordinarily Resident (Amendment) Regulations (Northern Ireland) 2020 NISR 2020/25.

25 Private Tenancies (Coronavirus Modifications) Act (Northern Ireland) 2020 (chapter 2).

26 Northern Ireland Assembly (24 March 2020) Legislative Consent Motion: Coronavirus Bill.

27 Andrew Blick and Clive Walker, 'Why did government not use the Civil Contingencies Act?’ Law Society Gazette (London, 2 April 2020).

28 Clive Walker and Andrew Blick, 'Coronavirus legislative responses in the UK: regression to panic and disdain of constitutionalism' (Just Security, 2 May 2020). 
One particular area of concern highlighted by these authors relates to duties around coronial inquests, with concerns raised that 'death certification and coronial interventions are short-circuited by section 18 by enabling a doctor to certify the cause of death without the death being referred to a coroner'. ${ }^{29}$

As alluded to earlier, the coronial inquest system provides a key mechanism whereby the state can discharge its procedural duties under ECHR Article 2 to ensure there are prompt, effective investigations, independent of those responsible, into certain deaths.

Section 18(3) (with reference to Part 3 of schedule 13 of the Act) modifies NI death registration and coronial legislation. The Coroners Act (Northern Ireland) 1959 places duties on medical practitioners, registrars, undertakers, cohabitees, or persons in charge of a residence where a deceased person was residing to notify the coroner of certain deaths. Normally, this includes deaths from illness and natural causes if a medical practitioner has not seen and treated the deceased within 28 days of their death. The Coronavirus Act, however, removes this requirement, meaning deaths attributed to natural causes, where the deceased has not been seen by a doctor, no longer have to be notified to the coroner. 30

This means, despite the duties under Article 2 ECHR, that deaths in which acts or omissions of public authorities are a factor (including through a failure to regulate private sector providers) may no longer need to be referred to the coroner for investigation. This would include removing the obligation to notify from the owners of care homes where a resident has died from suspected COVID-19 without seeing a doctor in which issues relating to their care and circumstances may have played a part.

By contrast, in Scotland on 13 May 2020 the Lord Advocate James Wolffe QC instructed that deaths in the following categories be reported to the procurator fiscal (the Scottish equivalent of a coroner):

\section{Ibid.}

30 Section 7 of the Coroners Act (Northern Ireland) 1959 (chapter 15).

'7 [Words* in s. 7 omitted (temp.) (26.3.2020) by virtue of Coronavirus Act 2020 (c. 7), Sch. 13 para. 26]: Duty to give information to coroner: Every medical practitioner, registrar of deaths or funeral undertaker and every occupier of a house or mobile dwelling and every person in charge of any institution or premises in which a deceased person was residing, who has reason to believe that the deceased person died, either directly or indirectly, as a result of violence or misadventure or by unfair means, or as a result of negligence or misconduct or malpractice on the part of others, or from any cause other than natural illness or disease [*for which he had been seen and treated by a registered medical practitioner within twenty-eight days prior to his death], or in such circumstances as may require investigation (including death as the result of the administration of an anaesthetic), shall immediately notify the coroner within whose district the body of such deceased person is of the facts and circumstances relating to the death. 
- all Covid-19 or presumed Covid-19 deaths where the deceased might have contracted the virus in the course of their employment or occupation.

- all Covid-19 or presumed Covid-19 deaths where the deceased was resident in a care home when the virus was contracted. 31

The issue of inquests into deaths from COVID-19, particularly of frontline NHS staff, further became controversial following guidance issued in April by the Chief Coroner for England and Wales. ${ }^{32}$ This guidance 'reminded' coroners that inquests were not the forum to address concerns 'about high-level government or public policy' and specifically told coroners not to look at provision of personal protective equipment (PPE) to NHS staff. ${ }^{33}$ This led to the Committee on the Administration of Justice (CAJ) and other human rights organisations writing to the NI judiciary to raise concerns that such an approach was not compliant with ECHR Article 2 and seeking assurances that similar guidance would not be issued in NI. A prompt response was received from the Presiding Coroner, Mrs Justice Keegan, making clear 'there is no intention to issue guidance in this jurisdiction. Coroners in this jurisdiction will have discretion to investigate any death on a case-bycase basis, and will do so based on the individual merits of each case'. ${ }^{34}$

31 Crown Office and Procurator Fiscal Office, 'Revised guidance on reporting of deaths during coronavirus outbreak' (15 May 2020).

32 Robert Booth, 'NHS staff coronavirus inquests told not to look at PPE shortages' The Guardian (London, 29 April 2020).

33 Chief Coroner HHJ Mark Lucraft QC, 'Guidance No 37 Covid-19 deaths and possible exposure in the workplace’ (28 April 2020), paragraph 13.

' 13 . In the usual way, it is a matter of judgment for the individual coroner to decide on the scope of each investigation. The coroner must consider the question of scope in the context of providing evidence to answer the four statutory questions. Coroners are reminded that an inquest is not the right forum for addressing concerns about high-level government or public policy. The higher courts have repeatedly commented that a coroner's inquest is not usually the right forum for such issues of general policy to be resolved: see Scholes v SSHD [2006] HRLR 44 at [69]; R (Smith) v Oxfordshire Asst Deputy Coroner [2011] 1 AC 1 at [81]. In the latter case, Lord Phillips observed that an inquest could properly consider whether a soldier had died because a flak jacket had been pierced by a sniper's bullet, but would not "be a satisfactory tribunal for investigating whether more effective flak jackets could and should have been supplied by the Ministry of Defence." By the same reasoning, an inquest would not be a satisfactory means of deciding whether adequate general policies and arrangements were in place for provision of personal protective equipment (PPE) to healthcare workers in the country or a part of it.'

34 Correspondence from the Private Office of the Presiding Coroner to CAJ (4 May 2020). 
The Coronavirus Act contains measures which are NI-specific. ${ }^{35}$ These include (under section 51, schedule 21) powers for public health officers (but also police and immigration officers) to detain 'potentially infectious persons' for health screening and assessment; and under schedule 22 powers vested in the First Minister and Deputy First Minister to restrict events, gatherings and close premises. Significantly, the Coronavirus Act also makes major changes to the PHANI 1967, schedule 18, inserting temporarily a new Part 1A. This new part provides sweepingly broad regulation-making powers vested in the NI Department of Health. This includes powers in section 25B over international travel (medical examination, quarantining etc of passengers). Section 25C empowers regulations that place duties on medical professionals and requirements on matters such as keeping children off school, restrictions on events or gatherings and burials. Powers also extend to compelling medical examination or quarantining and the closure of premises.

Some safeguards are imposed on the regulation-making powers through sections $25 \mathrm{D}$ and $25 \mathrm{E}$. Under section $25 \mathrm{~F}$ the regulations may create new criminal offences. Under section 25P regulations are normally subject to prior Assembly scrutiny in draft followed by negative resolution, but an 'emergency procedure' under section 25Q enables passage without prior Assembly scrutiny when necessary 'for reasons of urgency'.

These regulation-making powers have become the basis of the main NI COVID-19 emergency regulations.

\section{THE HEALTH PROTECTION (CORONAVIRUS, RESTRICTIONS) REGULATIONS (NORTHERN IRELAND) 2020}

The Health Protection (Coronavirus, Restrictions) Regulations (Northern Ireland) 2020 (the NI COVID-19 Regulations) were made on 28 March 2020 by the Health Minister Robin Swann MLA using the PHANI 1967 powers augmented by the Coronavirus Act 2020. These regulations have to be reviewed every 21 days.

The first two regulations cover commencement, interpretation, the 'emergency period' and review process. Regulations 3 and 4 contain powers to close premises and businesses during the emergency. Notably, these powers are similar to those vested in the First Minister

35 The full range of powers and duties in the Coronavirus Act will not be set out in this commentary. The measures range from those to assist with the emergency registration provisions for medical and social work professionals to changing safeguards over surveillance powers. 
and deputy First Minister in the Coronavirus Act (the latter of which were not then commenced, presumably given the duplication).

The two other substantive provisions in the original NI COVID-19 Regulations are regulation 5, which obliges persons not to leave home without reasonable excuse, and regulation 6 , which restricts gatherings of more than two persons in a public place, with limited exceptions. Regulation 7 then covers enforcement powers, while regulation 8 deals with offences and penalties. ${ }^{36}$ The following commentary will focus on regulations 5 and 6 , given the human rights impact of these regulations on matters such as freedom of movement, freedom of assembly and rights to family life.

\section{REGULATION 5: THE 'STAY AT HOME’ DIRECTIVE}

Regulation 5 stipulates you should not leave your home 'without reasonable excuse'. Around a dozen 'reasonable excuses' for leaving your normal place of residence were originally listed, but the list is not exhaustive. It includes leaving home to get food or medicine, for essential work, seeking medical assistance, to escape risk of harm (relevant to domestic abuse), to move children in shared care arrangements and so on.

Another permitted reason for leaving your home is 'to take exercise either alone or with other members of their household'. There was some initial contestation as to whether you could drive to a place to then take exercise. The regulations themselves do not provide further interpretation of the provision and in practice clarification was left to the PSNI as the enforcement body. There were, however, contradictory messages. The PSNI often follows National Police Chiefs' Council (NPCC) guidance. Media coverage clarified that NPCC guidance permitted driving a reasonable distance to do exercise. 37 On the same day this was publicised, the PSNI appeared to take a different line with a senior officer stating that 'anyone travelling from home for exercise if they do not need to is in breach of lockdown restrictions'. ${ }^{38}$ The Newsletter reported that the PSNI in Carrickfergus went further by posting on Facebook 'Exercise begins and ends at your front door. By that I do not mean walking from your front door to your car to

36 Regulations 9-14 deal with fixed penalty notices for offences under the regulations and related enforcement procedures. Regulation 15 provides that the NI COVID-19 Regulations will expire within six months of coming into operation.

37 Jamie Grierson, 'Driving to take a walk is lawful during England lockdown, police told' The Guardian (London, 16 April 2020).

38 Julian O'Neill and Jayne McCormack, 'Coronavirus: travelling for exercise "breaching restrictions"” BBC News NI (Belfast, 16 April 2020) (emphasis added). 
drive somewhere for exercise. This will not be tolerated ....39 In contradiction, the PSNI advice on its own website at the time was limited to 'encouraging' people not to drive to local beauty spots for their daily exercise. This was subsequently removed.40

The lack of legal certainty led to Executive discussion. On 24 April 2020 a statement was issued by the Executive Office (TEO) at the same time as an amendment was also made to the NI COVID-19 Regulations to allow persons to visit graveyards (subject to a duty on persons responsible for burial grounds to take all reasonable measures to ensure social distancing by the public). The TEO stated:

The Executive has also agreed to amend the Regulations to clarify the circumstances in which a person can leave the house to exercise, including reasonable travel to exercise. For example, a drive to a safe space or facility would be permitted. However, taking a long drive to get to a beach, or resort where numbers of people may gather is unlikely to be regarded as reasonable, even for exercise. ${ }^{41}$

An amendment was then added stating that the regulations are still breached unless any 'associated travel' with exercise is reasonable. 42 It is, of course, only a breach of the regulations per se, rather than any associated guidance or advice (on matters such as social distancing), that triggers the use of enforcement powers.

By 23 April 2020 controversy over the use of PSNI enforcement powers led to a temporary direction that required the approval of a senior PSNI officer before a fine or community resolution notice (CNR) could be issued.43 A few days later, on 28 April 2020, the Department of Health and PSNI issued a joint statement. This makes no reference to the 'drive for exercise' amendment and, rather than providing further guidance, only appears to add to the lack of legal certainty over the rules. The statement, which opens by curiously referring to the 'regulations on social distancing', instead emphasises officer discretion and states that individual answers for 'countless hypothetical scenarios' cannot be given. 44

39 Sam McBride 'The police's made-up coronavirus law ought to unsettle anyone who understands democracy' The Newsletter (Belfast, 18 April 2020).

40 PSNI, 'COVID-19 advice and information'.

41 The Executive Office, 'Executive approves opening of cemeteries on restricted basis' (24 April 2020).

42 Health Protection (Coronavirus, Restrictions) (Amendment) Regulations (Northern Ireland) 2020 NISR 2020/71, regulation 2(4)(b).

43 Rodney Edwards, 'PSNI chief tells officers to seek approval before issuing coronavirus fines’ Belfast Telegraph (Belfast, 23 April 2020).

44 Department of Health, 'Joint statement by the Department of Health and the Police Service of Northern Ireland’ (28 April 2020). 
By 4 May 2020385 fixed penalty notices and 655 CNRs had been issued. The temporary direction requiring senior officer approval was still in place at 7 May 2020. By this time the PSNI reported that the Police Ombudsman had only received 24 complaints that were COVID-19 related, all in the 'less serious' category. 45 Whilst the initial policing response was not widely contested as having been heavy handed, action taken against Black Lives Matter protestors on 6 June 2020, proved particularly controversial, in part due to the use of extended enforcement powers which had only been commenced the night before through the 'emergency procedure'. 46

Whilst the application of the regulations to the anti-racism protests is further covered below in relation to restrictions on gatherings, regulation 5 is also engaged as protestors still require a 'reasonable excuse' to leave home. There is no explicit 'reasonable excuse' to leave your home to participate in a protest. However, given the list is nonexhaustive and protest activity engages fundamental human rights under the ECHR (to freedom of assembly and expression etc) it would appear disproportionate to interpret regulation 5 as not permitting a person to leave their home for any expressive activity (which would include a one-person protest).

The most common form of expressive free assembly from the initiation of the regulations was the weekly clap for NHS and other essential workers whereby individual households congregated to clap at $8 \mathrm{pm}$ each Thursday. Save for persons with front gardens, this technically, in standing on the pavement, involved leaving your residence. Presumably, however, this socially distanced activity was rightly read as constituting a 'reasonable excuse' to leave your home.

On 19 May 2020 an amendment to the regulations added further 'reasonable excuses' to the explicitly permitted reasons to leave your residence, two of which were to take part in 'outdoor activity' and 'outdoor gatherings' ${ }^{47}$ Both concepts can be interpreted as permitting persons to leave their home for inter alia protest activity although neither is defined. The 'outdoor gathering' provision was linked to a new regulation 6A, which permitted 'outdoor gatherings' of up to six persons who are not members of the same household (or any number of persons who are members of the same household).

45 PSNI, 'Chief Constable's written report to Northern Ireland Policing Board, Thursday 7th May 2020 - COVID-19’ (7 May 2020) paragraph 4(b)(f)(g).

46 Amnesty International UK and CAJ (n 6).

47 Health Protection (Coronavirus, Restrictions) (Amendment No 3) Regulations (Northern Ireland) 2020 NISR 2020.84, regulation 2(3). 


\section{REGULATIONS 6 AND 6A - RESTRICTIONS ON GATHERINGS}

The original regulation 6 prohibited all gatherings in a public place subject to several limited exemptions. 48 This changed on 19 May 2020 when the restrictions became subject to regulation 6A on 'outdoor gatherings' of up to six persons. Regulation $6 \mathrm{~A}$ is not qualified to a public place with the intention that it would also cover private spaces such as gardens. ${ }^{49}$ The formulation of regulation $6 \mathrm{~A}$ is, however, permissive, unlike regulation 6 which imposes a prohibition (but does not apply to private spaces, albeit persons from outside a household would still need a 'reasonable excuse' under regulation 5 to attend a gathering in a private space).

In the NI COVID-19 Regulations, there is no interpretation of the term 'gathering'. The equivalent provision in COVID-19 regulations in England defines gathering (from 1 June 2020) as 'when two or more people are present together in the same place in order to engage in any form of social interaction with each other, or to undertake any other activity with each other'. 50

The application of the regulations to protests became particularly controversial from Saturday 6 June 2020 in relation to the policing operation over Black Lives Matter protests in Belfast and DerryLondonderry. Despite efforts to ensure social distancing at the protest, around 70 fines or CNRs were issued to anti-racism protestors, mostly at the Derry protest, with PSNI officers expressly citing breaches of regulation 6A over 'gatherings' of more than six persons. Contrast was also drawn with a counter-protest to the anti-racism protests the following Saturday (13 June 2020, the 'protect our statues' protest) where no fines or CNRs were issued, although evidence was gathered. 51 Complaints from Black Lives Matter protestors led to the Police Ombudsman launching an investigation into PSNI consistency in enforcing the NI COVID-19 Regulations at large gatherings. 52

48 These exemptions included where all persons were from same household; for essential work purposes; to attend a funeral (although regulation 5(g) usually restricts attendees to household members and close family); or when 'reasonably necessary' to provide care, emergency assistance, fulfil a legal obligation or move house. In addition to qualified exemptions subsequently being added for marriage ceremonies, drive-in entertainment/worship.

49 Minister Lyons, Northern Ireland Assembly Official Report (16 June 2020, $5.30 \mathrm{pm}$ ) Health Protection (Coronavirus, Restrictions) (Amendment No 4) Regulations (Northern Ireland) 2020.

50 Health Protection (Coronavirus, Restrictions) (England) (Amendment) (No 3) Regulations 2020 SI 2020/558, regulation 2(7).

51 PSNI, 'Statement from Assistant Chief Constable Barbara Gray' (13 June 2020).

52 Police Ombudsman, 'Police Ombudsman to look at how police have enforced regulations on large public gatherings' (17 June 2020). 
The enforcement action against anti-racism protestors prompted, among other matters, questions as to how 'gathering' was being interpreted, given that the protest organisers had gone to considerable efforts to ensure social distancing. This contrasted to a number of large social gatherings that had taken place prior to the Black Lives Matter protests and had not reportedly faced such enforcement action. Comparisons were even made between socially distanced protests and distanced queues for supermarkets, and in particular the IKEA Belfast store (the reopening of which had drawn considerable numbers). 53 Whilst an IKEA or supermarket queue would not lend itself to constitute a 'gathering' under the definition in English regulations, the lack of a definition in the NI COVID-19 Regulations leaves this contention more open.

A related question therefore concerns whether the anti-racism protests of 6 June 2020 should have been treated as one 'gathering' or as numerous separate 'gatherings' due to the express efforts of organisers to ensure the protests were socially distanced. A comparator can be drawn with those who participated in the expressive activity of the NHS clap on the pavement who were not considered to be one gathering. A further comparative example occurred several days after the anti-racism protests. Reportedly, around 100 people lined the streets of Ballymena to pay respects at a funeral but did so with social distancing in place, and without similar PSNI intervention. ${ }^{54}$ At the time of writing, however, there is considerable political upheaval in relation to the provisions of regulations and the funeral of a senior republican in Belfast on Tuesday 30 June 2020, at a time when outdoor gatherings of up to 30 persons (with recommended social distancing) were permitted. This has again raised questions, among other matters, as to whether large numbers of people lining the route of a funeral are to be treated as one or numerous separate gatherings, or even as part of the funeral. 55

There are therefore significant legal certainty issues with the definition and interpretation of 'outdoor gathering', including when gatherings are to be considered as one or numerous different gatherings. As well as the policing operation itself, a further point of concern in relation to the application of the regulations related to the extension of enforcement powers over regulation $6 \mathrm{~A}$ on the eve of the protests. This is explored further below.

53 See $B B C$ News (n 6) and 'Coronavirus: long queues form as Ikea in Belfast reopens' BBC News NI (Belfast, 1 June 2020).

54 'Funeral of Liam Neeson's mother Kitty held in Ballymena' Belfast Telegraph (Belfast, 9 June 2020).

55 See, for example, Northern Ireland Assembly Official Report (30 June 2020, $5.30 \mathrm{pm}$ ) Health Protection (Coronavirus, Restrictions) (Amendment No 5) Regulations (Northern Ireland) 2020. 


\section{AMENDMENTS TO THE NI COVID-19 REGULATIONS, ALWAYS 'BY REASON OF URGENCY'?}

The NI COVID-19 Regulations (of 28 March 2020) were first amended on 24 April 2020. By 30 June 2020, nine further amendment regulations had been made. All but the first amendment regulation have followed the NI Executive publishing (on 12 May 2020) its roadmap Coronavirus: Executive Approach to Decision Making, providing for a five-step process to move out of lockdown. 56

Many amendments have therefore been to implement a gradual relaxation of restrictions. There have, however, also been 'technical' amendments, presumably to correct earlier oversights, gaps or drafting errors. 57

The aforementioned regulation 6A permitting outdoor gatherings of up to six persons not from the same household was announced by the NI Executive on Monday 8 May 2020.58 Accordingly and unsurprisingly, from Tuesday morning many persons went outdoors to meet family members and friends from outside their household for the first time since the lockdown. Technically, however, such gatherings during the daylight hours breached the regulations. The required amendment was not ultimately laid before the Assembly until 9am on Wednesday 20 May 2020 with it retrospectively coming into force on the Tuesday night at $11 \mathrm{pm} .{ }^{59}$ Whilst this issue many have passed largely unnoticed, it does highlight the risk of a brief gap between policy announcements and necessary legal changes.

Whilst from 19 May 2020 'outdoor gatherings' were permitted under regulation $6 \mathrm{~A}$, no consequential amendment was made to the regulations to extend the enforcement powers and offences for breaches of regulation $6 \mathrm{~A}$ at the time. Amendment regulation No 4, of 21 May 2020, also did not make this change. The change was ultimately made by amendment regulation No 5 and proved controversial. The amendment was made and laid before the Assembly at $3 \mathrm{pm}$ and $5 \mathrm{pm}$ respectively on Friday 5 June 2020. Whilst other changes brought in by amendment No 5 did not come into force until $11 \mathrm{pm}$ on Sunday 7 June 2020, the provision that made regulation 6A an enforceable offence instead came into force at $11 \mathrm{pm}$ on the Friday itself - 5 June

56 The Executive Office, 'Executive publishes coronavirus recovery strategy' (12 May 2020).

57 See, for example, amendments made by the Health Protection (Coronavirus, Restrictions) (Amendment No 2) Regulations (Northern Ireland) 2020 NISR 2020/82, regulation 2(4)(a); 2(5)(a).

58 The Executive Office, 'Executive daily update: initiatives to deal with coronavirus' (18 May 2020).

59 Health Protection (Coronavirus, Restrictions) (Amendment No 3) Regulations (Northern Ireland) 2020 NISR 2020/84. 
2020 . The significance of this was that the PSNI were then able to use the newly extended powers the following day at the Black Lives Matter protests. 60

Among other matters, this brings into focus the use of the 'emergency procedure' to make amendments to the regulations. As set out above, the PHANI 1967 regulation-making powers have a standard procedure, under section 25P, requiring prior Assembly scrutiny, and an 'emergency procedure' under section 25Q whereby 'by reason of urgency, it is necessary to make the regulations without a draft being so laid and approved'. To date, however, all amendments to the NI COVID-19 Regulations have relied on the section 25Q emergency procedure. In human rights terms, amendments that actually ease restrictions will raise few issues, however, the difference with the amendment to regulation $6 \mathrm{~A}$ was that it extended criminal offences. It is at best questionable whether this was necessary 'by reason of urgency' in advance of anti-racism protests, in a context whereby powers to enforce regulation $6 \mathrm{~A}$ had not been available for several weeks since its introduction and other large gatherings had taken place.

One explanation for this was that the Department of Health intentionally fast-tracked the amendment and its commencement specifically to ensure the powers were available for the Black Lives Matter protests. Unless objective and reasonable justification for doing so can be provided, this would raise questions of differential and discriminatory treatment. An alternative explanation is that the timing of the amendment and its commencement were coincidental: the Department of Health was merely using the opportunity of a further amendment to make a technical fix to a previous drafting error. Whilst this account would not explain the accelerated commencement, it would also prompt questions as to whether the use of the section 25Q 'emergency procedure' was appropriate.

On 16 June 2020, the TEO Junior Minister Gordon Lyons MLA addressed the Assembly on the matter. The Minister stated the lack of enforcement powers over regulation 6A had been a 'drafting error' that was 'noticed and corrected on the same day' (ie 5 June 2020) by amendment regulation No 5. The Minister also stated that the PSNI had been 'unaware of the drafting error until it was drawn to their attention on the afternoon of the 5th June' but that he had been advised that the PSNI between 19 May and 5 June 2020 had not issued any fines (fixed penalty notices) for breaches of regulation $6 \mathrm{~A}$. The Minister added that the 'timing of the Black Lives Matter protest was purely coincidental,

60 Health Protection (Coronavirus, Restrictions) (Amendment No 5) Regulations (Northern Ireland) 2020 NISR 2020/96, regulation 1(3). 
but the enforcement of the regulations is a matter for the PSNI' 61 This draws further questions as to whether it was appropriate therefore to use the emergency procedure to extend criminal offences and related enforcement powers that the PSNI had apparently had no need for in the weeks from 19 May 2020 until the anti-racism protests.

On 11 June 2020 a further amendment regulation, No 6, amended the regulation $6 \mathrm{~A}$ provision on 'outdoor gatherings' to increase the permitted number from six to 10 persons. 62 However, in a seemingly further drafting error, a consequential amendment was not made to the enforcement powers over regulation 6A meaning the PSNI were still empowered to disperse gatherings of seven or more (rather than 11 or more) persons. 63 This was ultimately rectified on 25 June 2020 by amendment regulation No 8.64 Subsequently amendment regulation No 9 extended the numbers for gatherings under regulation 6 or $6 \mathrm{~A}$ to 30 persons. 65

\section{LEGAL CERTAINTY AND PUBLICLY AVAILABLE INFORMATION ON THE NI COVID-19 REGULATIONS}

A Department of Health website, with some short delays, has largely been the first place regulations are published, ahead of the statute law database.66 This website initially provided no further information beyond links to the original NI COVID-19 Regulations and each amendment regulation. This finally changed on 5 June 2020 when accessible guidance was uploaded on the scope of the regulations. $67 \mathrm{~A}$ consolidated version of the regulations was also not uploaded until 12

61 Northern Ireland Assembly Official Report (16 June 2020, 5.30pm) Health Protection (Coronavirus, Restrictions) (Amendment No 4) Regulations (Northern Ireland) 2020.

62 Health Protection (Coronavirus, Restrictions) (Amendment No 6) Regulations (Northern Ireland) 2020 NISR 2020/103.

63 Health Protection (Coronavirus, Restrictions) (Amendment No 8) Regulations (Northern Ireland) 2020 NISR 2020/118, regulations 2(7) and 1(2).

64 Health Protection (Coronavirus, Restrictions) (Amendment No 9) Regulations (Northern Ireland) 2020 NISR 2020/121, regulations 2(3)(a) and 2(4).

65 See regulation 7(9A) of the NI COVID-19 Regulations (as amended up to Amendment No 6).

66 Department of Health, Health Protection (Coronavirus, Restrictions) (Northern Ireland) Regulations 2020 (first published 28 March 2020, version updated 30 June 2020). The Statute Law Database is found at Gov.uk.

67 Department of Health, 'Guidance on the restrictions in Northern Ireland and Public Health Advice’ (5 June 2020 and subsequently updated 12 June 2020). 
June 2020. Prior to this, readers would have needed to piece together the various amendment regulations themselves. 68

During this time the PSNI COVID-19 information website deferred to this Department of Health website and was otherwise limited to setting out what were the penalties for infractions against the regulations. 69 The Public Health Agency public information website also made only passing reference to some provisions in the NI COVID-19 Regulations. 70 The NI Direct website also contained limited information. ${ }^{71}$

Whilst some remedy was eventually provided on 5 June 2020, prior to this for over two months following the initial commencement of the NI COVID-19 Regulations no guidance accessible to the public that accurately reflected the scope of far-reaching emergency law was readily available.

\section{ENFORCEMENT POWERS}

Regulation 7 relates to powers to enforce the NI COVID-19 Regulations. Regulation 7(1) ominously and with echoes of the vagueness and arbitrary nature of the Special Powers Acts originally provided that: 'A relevant person may take such action as is necessary to enforce any requirement imposed by regulation 3,4 or 6'. This therefore covers regulations 3 and 4 (duties to close businesses and premises etc) and regulation 6 on public gatherings. (Enforcement over regulation $6 \mathrm{~A} / 6 \mathrm{~B}$ was subsequently added.)

A 'relevant person' means a police officer or anyone else designated by the Department of Health for this purpose (to date on 15 May 2020 one designation order was also issued covering council officers). ${ }^{72}$

In relation to enforcement of the 'stay at home' rule, regulation $7(3)$ provides powers to direct a person to return to their residence, or remove them to same, when a relevant person 'considers' they have left their home without reasonable excuse. Save for the provision to 'direct a person to return' home being interpreted as permitting stopping that person, there are no stop and question powers or other provisions to

68 Health Protection (Coronavirus, Restrictions) Regulations (Northern Ireland) 2020 NISR 2020/55 (consolidated to include SR 2020/71, SR 2020/82, SR 2020/84, SR 2020/86, SR 2020/96 \& SR 2020/103).

69 PSNI (n 40).

70 Public Health Agency, 'COVID-19: information for the public', namely 'only go outside for permitted shopping, health reasons, work or exercise. If you go out, stay 2 metres (6ft) away from other people at all times. Groups of 4-6 people who do not share a household can meet outdoors, maintaining social distancing'.

71 NI Direct, 'Coronavirus (COVID-19): staying at home and self-isolation'.

72 Department of Health, 'Designations under the Health Protection (Coronavirus, Restrictions) Regulations (Northern Ireland) 2020’ (15 May 2020). 
facilitate officers ascertaining (where not obvious) whether a person has a reasonable excuse for being outside their residence.

\section{PASSENGER QUARANTINE: THE OTHER NI COVID-19 REGULATIONS}

Two further and separate emergency regulations were made by the Department of Health on Friday 5 June 2020 using the modified PHANI 1967 powers. 73 These regulations were the statutory basis for a 14-day quarantine (through self-isolation) rule on incoming passengers as a preventative measure against imported cases of COVID-19 and came into force on Monday 8 June 2020 to coincide with similar regulations in England.

There was some prior, but limited, Assembly scrutiny of these regulations. In part due to the policy not being signed off despite such a system having been under discussion for some time. ${ }^{74}$ The Irish government initiated its system on 24 April 2020.75 The UK government confirmed its intention to take this measure as part of its COVID-19 recovery strategy in early May, with a subsequent ministerial statement setting out that devolved administrations would need to set out their own enforcement approaches. ${ }^{76}$

In common between Ireland and the UK are requirements on incoming passengers to fill in a COVID-19 passenger locator form, usually providing their details and address at which they will selfisolate for 14 days. The main difference is that the UK government draws its COVID-19 quarantine border around the whole CTA (the open border zone consisting of the UK, Ireland, Channel Islands and Isle of Man). The Irish government meanwhile (presumably in the

73 The main provisions are found in the Health Protection (Coronavirus, International Travel) Regulations (Northern Ireland) 2020 NISR 2020/90. A second regulation made at the same time - the Health Protection (Coronavirus, Public Health Advice for Persons Travelling to Northern Ireland) Regulations (Northern Ireland) 2020 - obliged airlines/ferry companies on services directly to Northern Ireland from outside the Common Travel Area to provide information about the NI quarantine rules.

74 Committee for Health, Minutes of Proceedings and Minutes of Evidence (28 May 2020), item 6: 'SL1 The Health Protection (Coronavirus, International Travel) Regulations (Northern Ireland) 2020'.

75 This was then set up on a statutory basis from 28 May 2020 under the Health Act 1947 (Section 31a - Temporary Requirements) (COVID-19 Passenger Locator Form) Regulations 2020.

76 Home Office, 'Home Secretary announces new public health measures for all UK arrivals' (22 May 2020). For a broader narrative on the background see: CAJ, 'COVID 19, passenger quarantine and the Common Travel Area (CTA): how are requirements for 14 day self-isolation intended to work in the CTA?' (May 2020). 
context of the very high number of COVID-19 cases in Great Britain) draws its boundary around the island of Ireland, exempting passengers that travel from NI, but not those who travel from the island of Britain.

The passenger quarantine regulations have been controversial with the airlines and airports. In response to criticism from Belfast International Airport that the quarantine rules were 'ill-timed, illthought through and illogical' and a 'crazy, crazy idea', the First Minister Arlene Foster reportedly told Good Morning Ulster that the quarantine measures were a 'reserved issue' that the UK government would review every three weeks. ${ }^{77}$ The NI regulations were, however, made by the NI Department of Health and are subject to review by the NI Department of Health every three weeks. ${ }^{78}$

The NI COVID-19 Regulations are made by powers under the PHANI 1967 that make reference to international rather than domestic passengers and follow the UK government position of drawing the boundary around the CTA. ${ }^{79}$ In practice, this means inbound passengers to NI from places like Germany and Greece, with low COVID-19 rates, are subject to the 14-day self-isolation rule, but passengers on flights and ferries from England, where rates are high, are not.

The NI regulations do have the air of having been overly copied and pasted from their English equivalents. This is notable in the almost identical schedule 2 on exemptions to the NI self-isolation regulations that, among other matters, cover Channel Tunnel train crews and maintenance workers. 80 Whilst this addition may be immaterial, more problematic are provisions that relate to incoming passengers entering NI over the land border. This is manifest in obligations for the UK passenger locator form to be provided 'on arrival' in NI and in the definition of 'transit passengers'.

The NI (and England) international passenger regulations close what had been termed the 'Dublin loophole' in the UK media. This referred to passengers returning to the UK re-routing their journey through Dublin airport to evade the UK quarantine requirements. This issue is addressed by applying the self-isolation rules to arrivals who have been outside the CTA in the preceding 14 days. ${ }^{81}$ The NI regulations do not, however, close the 'Belfast loophole' whereby, for example, London-based employees of a company travelling to Dublin re-route

77 'Coronavirus: Quarantine "stake through the heart" of airport' BBC News NI (Belfast, 15 June 2020).

78 Health Protection (Coronavirus, International Travel) Regulations (Northern Ireland) 2020, SRNI 2020/90, regulation 11.

79 Specifically, temporarily inserted sections $25 \mathrm{~B}$ and $25 \mathrm{~F}(2)$.

80 Health Protection (Coronavirus, International Travel) Regulations (Northern Ireland) 2020, SRNI 2020/90, schedule 2, paragraph 12.

81 Ibid regulation 3(1)(b) and 4(1)(b). 
their journey via a London-Belfast flight with onward bus travel to Dublin. This risks creating public health issues at NI transport hubs should it happen on a significant scale.

A more immediate question relates to passengers arriving in Dublin Airport who then travel to NI either as NI residents or in 'transit' to Donegal.

Whilst the PHANI 1967 powers provide for the implementation of international agreements, no arrangement was entered into with the Irish government for reciprocal use of data from the UK and Irish passenger locator forms respectively (a reciprocal arrangement is in place if the form is completed in England, Scotland or Wales).

By way of illustration, the process for an NI resident arriving from outside the CTA into Belfast International Airport is fairly simple. Their travel operator under law will have had to provide information on the self-isolation and form-filling requirements. The UK passenger locator form can be filled in online up to 48 hours before arrival, or in person at passport control on arrival at the airport where facilities will be available (the UK form is digital).

By contrast, it is not clear how an NI resident landing into Dublin Airport from outside the CTA can do this. They will fill in the Irish government's passenger locator form at passport control (ticking the exemption for onward travel to NI). However, the passenger is then required by law to provide the UK passenger locator form 'on their arrival' in NI. This provision does not appear to anticipate the common scenario whereby the passenger will be arriving in NI in a moving vehicle across the land border where there is no passport control. Nevertheless, this passenger will commit an offence for not providing the UK form 'on their arrival' (subject to a reasonable excuse defence). 82 Whilst the passenger can also provide the UK form up to 48 hours before arrival, it is not clear how the passenger will know this, or how passengers without a smartphone will fill it in. ${ }^{83}$ Whilst NI law cannot place requirements in another jurisdiction, it is unclear why a reciprocal arrangement was not entered into to address this. Rather discussions were described as still 'ongoing' on matters such as information panels in each other's airports after the NI regulations had commenced. 84

A further question faces passengers transiting through NI over land: for example, a resident of Donegal returning home having landed back

82 Ibid regulation 3(2) and 6(1)(a).

83 For further detail, see: CAJ, 'Passenger quarantine and the Common Travel Area: the Health Protection (Coronavirus, International Travel) Regulations (Northern Ireland) 2020' (CAJ Briefing Note No 2, June 2020).

84 Freya McClements, 'NI Executive seeks panels in ports and airports outlining quarantine rules' Irish Times (Dublin, 9 June 2020). 
in Dublin Airport from outside the CTA. Unlike NI residents transiting home over land through the Republic, there is no exemption for such persons. This is as the definition of 'transit passenger' in the NI regulations (mirroring that of its English counterpart) is drafted to only cover passengers who do not enter the jurisdiction (ie those passing through an airport international transit lounge). 85 The passenger is therefore required to know about and fill in the UK passenger locator form online 'on arrival' at the land border (or 48 hours before). However, it is not clear if the form can be completed satisfactorily, as it has to include a UK address at which the passenger is to selfisolate. 86 Details required of any onward travel from the UK also do not appear to contemplate a journey by car. ${ }^{87}$ In addition to duties and related offences as regards filling out the UK form, such passengers are not among the exemptions to the requirement to self-isolate in NI. 88 Whilst the self-isolation requirement can end on departure from NI, this does not in itself remove the requirement. 89 Similar issues also arise for Donegal residents who return home via an NI airport. In summary, the provisions contain significant ambiguities in relation to their application to the land border.

\section{CONCLUSION}

Whilst the NI COVID-19 Regulations may enjoy the novelty of being the only emergency legislation in Northern Ireland's existence that has garnered universal mainstream political support, they have not been without their problems.

The UK government, rather than relying on existing powers, rushed through the vast Coronavirus Act 2020. This amended existing Stormont-era public health legislation to vest wide regulation-making powers in the NI Department of Health. Health officials dealing with the broader pandemic have therefore been managing the NI COVID-19 Regulations, which include criminal offences and enforcement powers more familiar to justice officials.

Despite the duties under Article 2 ECHR to ensure prompt, effective investigations into certain deaths where acts or omissions of public

Health Protection (Coronavirus, International Travel) Regulations (Northern Ireland) 2020, SRNI 2020/ 90, schedule 2, paragraph 5(2)) provides: “transit passenger" means a person who, on arrival in the United Kingdom, passes through to another country or territory without entering the United Kingdom”. Ibid schedule 1, paragraph 2(a)).

87 Ibid schedule 1, paragraph 2(J)).

88 Ibid. Exemptions (eg diplomats, cabin crew, transport workers) are set out in regulation 4(12)(d) and schedule 2.

Ibid regulation $4(7)$. 
authorities might have played a role, the Coronavirus Act 2020 temporarily amends NI coronial legislation to limit duties to notify the coroner of deaths. Whilst the Presiding Coroner has confirmed there is no intention in NI to issue guidance similar to the controversial provisions in England and Wales (that told coroners not to look at matters such as PPE shortages), similar provisions to those in Scotland (where instructions have been issued that deaths of frontline workers and care home residents must be referred to the coroner) have not been taken forward to date in NI.

Despite the decree-like nature of emergency regulation-making powers, regularly shifting policy necessitating resultant legislative amendments has been characterised by some gaps, errors and confusion. It took over two months for any accurate and duly updated official guidance on the scope of COVID-19 regulations to appear on an official website and slightly longer for a consolidated version of the regulations (that by then had been amended six times) to be made available.

Whilst the initial urgency to implement lockdown is apparent and many subsequent measures have eased lockdown, an 'emergency procedure' has been used for each amendment without prior Assembly scrutiny. This included to controversially extend criminal offences over gatherings on the eve of Black Lives Matter protests. There remain inconsistencies and ambiguities as to how, for example, 'gathering' is interpreted in relation to protest activity. There are also questions as to why an amendment to deal with what had been described as a drafting error to extend enforcement powers over outdoor gatherings became so 'urgent' on the eve of anti-racism protests, when the PSNI had hitherto neither tried to use such a power nor even noticed they did not have it.

A further set of NI-based regulations enforces a 14-day passenger self-isolation rule for persons entering NI from outside the UKIreland CTA. In part due to possible over-replication of provisions designed for England and the lack of a reciprocal agreement with the Irish government there are significant problems with these provisions. This is particularly the case for persons landing in Dublin airport who re-enter, or transit through NI via land and may unwittingly be caught by criminal offences given the construction of the regulations does not adequately anticipate such a scenario.

Whilst the current trajectory is for the easing of regulations, it is more than possible any second wave of the virus will prompt reintroduction as has happened in other places. There are plenty of lessons learned to be addressed in the interim. 